J. Perinat. Med. 3 (1975) 260

\section{Uterine hemodynamics and fetal response to vena caval occlusion in sheep}

\author{
Wolfgang Künzel, Eckardt Kastendieck, Ullrich Böhme, Axel Feige \\ Frauenklinik der Medizinischen Hochschule \\ Hannover, Dept. I: Geburtshilfe und Perinatologie; \\ Universitäts-Frauenklinik Würzburg
}

Received April 26, 1975. Accepted June 13, 1975.
In the last decade, the effect of posture upon circulatory hemodynamics in late pregnancy was repeatedly investigated. RoBERTs [13] and HoWARD et al. [12] draw first attention to the fact, that the profound decrease in blood pressure observed by pregnant women in supine position in the last trimester is probably due to a reduced venous return to the maternal heart following vena caval occlusion. Radiological studies [4] showed that inferior vena cava is normally occluded in supine position in late pregnancy and venous return occures via azygos and vertebran vein. But these studies were concerned about maternal hemodynamics and maternal outcome. Only few papers paid attention to the influence of these hemodynamic changes on fetal outcome $[1,14,7]$.

The cause for fetal deterioration due to inferior vena caval occlusion is not well understood. Placental sluice flow, demonstrated by Power and LoNGo [12], drop in maternal cardiac output and rise in total vascular resistance as shown by LeEs et al. [9], are possible explanations. Fetal oxygenation depends on uterine blood flow [8], but uterine hemodynamics were never studied during caval occlusion.

The aim of these experiments was therefore to investigate the alterations in uterine blood flow and uterine vascular resistance which occur during vena caval occlusion. Further attention was drawn to the reaction of the fetus. It could be shown, that during vena caval occlusion uterine blood flow decreased and uterine vascular resistance remained unchanged. The reduction of uterine blood flow was due to a reduction in perfusion pressure which results mainly to an increase in uterine vein blood pressure. Fetal heart rate was related to the change in uterine blood flow.

\section{Methods}

\subsection{Material}

These studies were performed on nine merinosheep. The gestational age ranged from 110 to 135 days. The maternal weight was $58 \mathrm{~kg}$ (SD $4.1 \mathrm{~kg}$ ), the mean fetal weight was $2.5 \mathrm{~kg}$ (SD $0.8 \mathrm{~kg})$.

Four sheep had one and four sheep had two fetuses.

\subsection{Anesthesia}

The sheep were anesthetized with pentobarbital; initial doses $15 \mathrm{mg} / \mathrm{kg}$ intravenously. The anesthesia was maintained with $5 \mathrm{mg} / \mathrm{kg} / \mathrm{h}$ by infusion. After tracheotomy and relaxation (Alloferin) the animals were mechanically ventilated (Tiberius, Draeger).

\subsection{Experimental procedure, measurements and calculations}

The abdomen was opened by a flank incisision, a cuff flow probe with an inner diameter of $5 \mathrm{~mm}$ was placed around the right uterine artery. To prevent spasm, the wall of the 
artery and the surrounding tissue was infiltrated with a local anesthetic, sometimes with poor success. The utcrine vein via tributaries and the femoral artery were cannulated.

The uterus was opened by an incisision in the uterine horn at the side where the flow probe was located. A catheter was placed in the fetal aorta via the femoral artery. Electrodes were fitted under the fetal skin for fetal ECG determination. An additional catheter was placed in the amniotic cavity and the uterus closed by a suture. The withdrawn amniotic fluid was replaced with the collected amniotic fluid.
The mean maternal arterial (MA) blood pressure (BP), uterine venous (UV) blood pressure, fetal arterial (FA) blood pressure and amniotic fluid pressure (AP) were measured with strain gauge transducers, blood flow was estimated with an electromagnetic flowmeter and fetal heart rate (FHR) was assessed by using a cardio-tachometer.

The vena cava was occluded below the renal vein for maximal 2 minutes, complete 9 times and of
Fig. 1. Mean arterial blood pressure, uterine venous blood pressure ( $\mathrm{mmHg}$ ) and uterine blood flow (as percent of control) following vena caval occlusion in 24 experiments in 9 sheep. The values are given as mean \pm standard error (S. E.).

During vena caval occlusion a sudden rise in uterine venous blood pressure was followed by a slow drop of arterial blood pressure and abrupt fall of uterine blood flow.

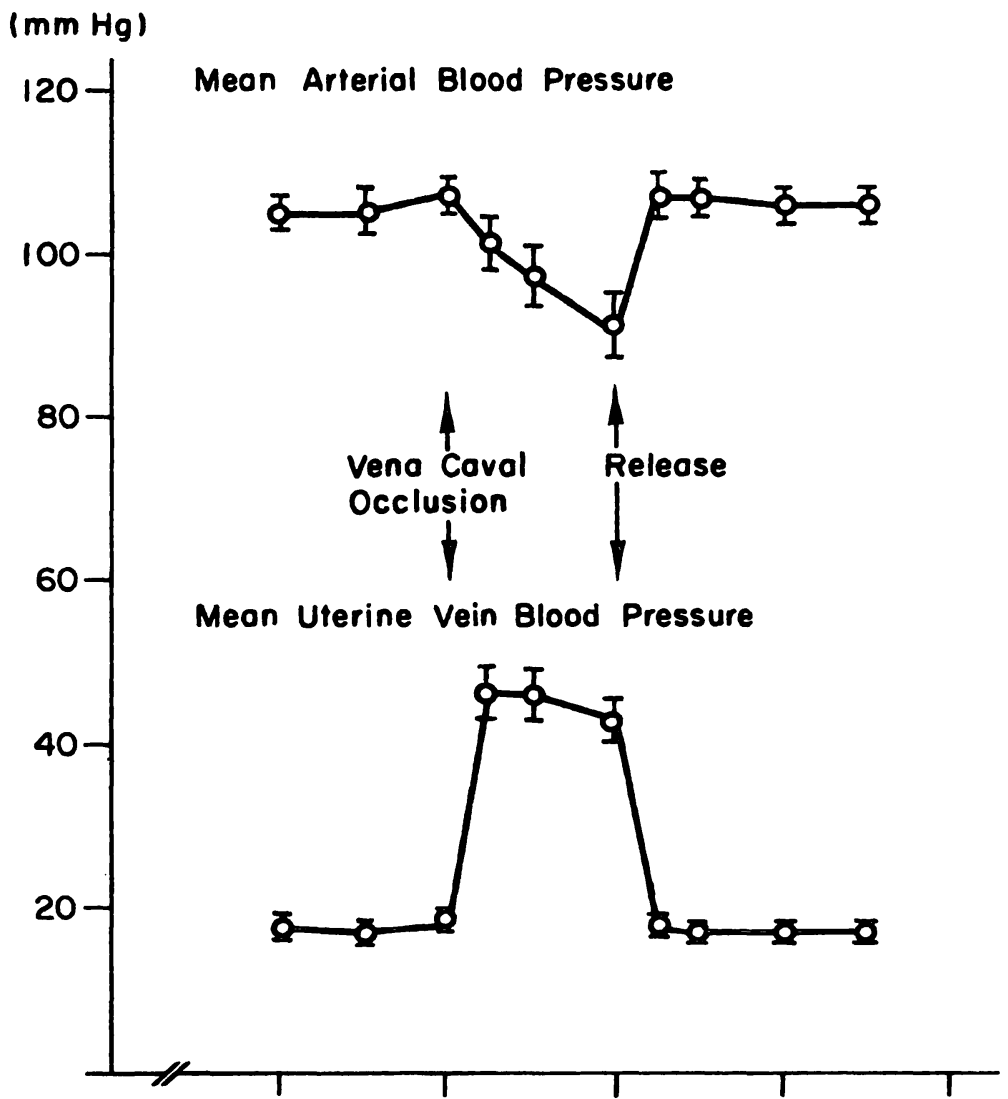

(\% of Control)

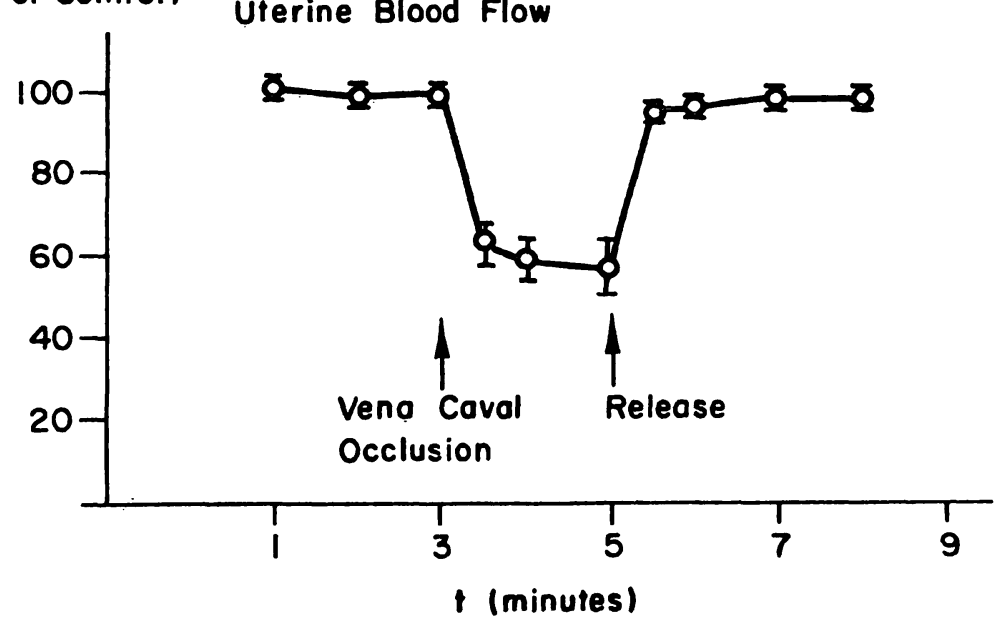


varying degree 15 times. Nine of the 24 occlusions were performed in 3 sheep with dead fetus to show any difference in uterine hemodynamics between the sheep with alive fetuses.

Uterine blood flow (UBF) measured in one uterine artery is not representative for the whole blood supply of the uterus. To compare the results, blood flow was expressed as percentage of control. Uterine vasculare resistance (U. V. R.) was calculated from perfusion pressure (MA-UV.) and the uterine blood flow. The response to vena caval occlusion (V. C. O.) is given as percent of control.

\section{Results}

\subsection{Vena caval occlusion and uterine hemodynamics}

\subsubsection{Uterine vein blood pressure}

The compiled data show an increase of uterine venous blood pressure during vena caval occlusion. The uterine vein blood pressure was $17 \pm 4 \mathrm{mmHg}$ before occlusion of the vena cava. During compression it rose to $47 \pm$ $13 \mathrm{mmHg} 30 \mathrm{sec}$. after occlusion and to $43 \pm$ $12 \mathrm{mmHg} 120 \mathrm{sec}$. after occlusion. Releasing the compression, the blood pressure dropped within $2 \mathrm{sec}$. to its value before occlusion (Fig. 1).

\subsubsection{Aterial blood pressure}

The mean arterial blood pressure before vena caval occlusion was $105 \pm 11 \mathrm{mmHg}$. Due to vena caval occlusion the blood pressure of the mother showed a steady decrease to $101 \pm$ $15 \mathrm{mmHg}$ after $30 \mathrm{sec}$. and $91 \pm 18 \mathrm{mmHg}$ after 2 min. of occlusion (Fig. 1). There was a sharp rise in maternal blood pressure after releasing the occlusion. The control value was reached within $30 \mathrm{sec}$. The decrease in maternal blood pressure following complete occlusion of the vena cava was not correlated to the rise in uterine vein blood pressure. The mean arterial blood pressure before vena caval occlusion ranged from $95 \mathrm{mmHg}$ to $128 \mathrm{mmHg} \quad(110 \mathrm{mmHg}$; SD 11).

Following complete vena caval occlusion the mean arterial BP dropped in every case ranging from $65 \mathrm{mmHg}$ to $108 \mathrm{mmHg}(90 \mathrm{mmHg}$; $\mathrm{SD}$ 16). The wide $\mathrm{SD}$ of the drop in $\mathrm{BP}(40 \mathrm{mmHg}$;

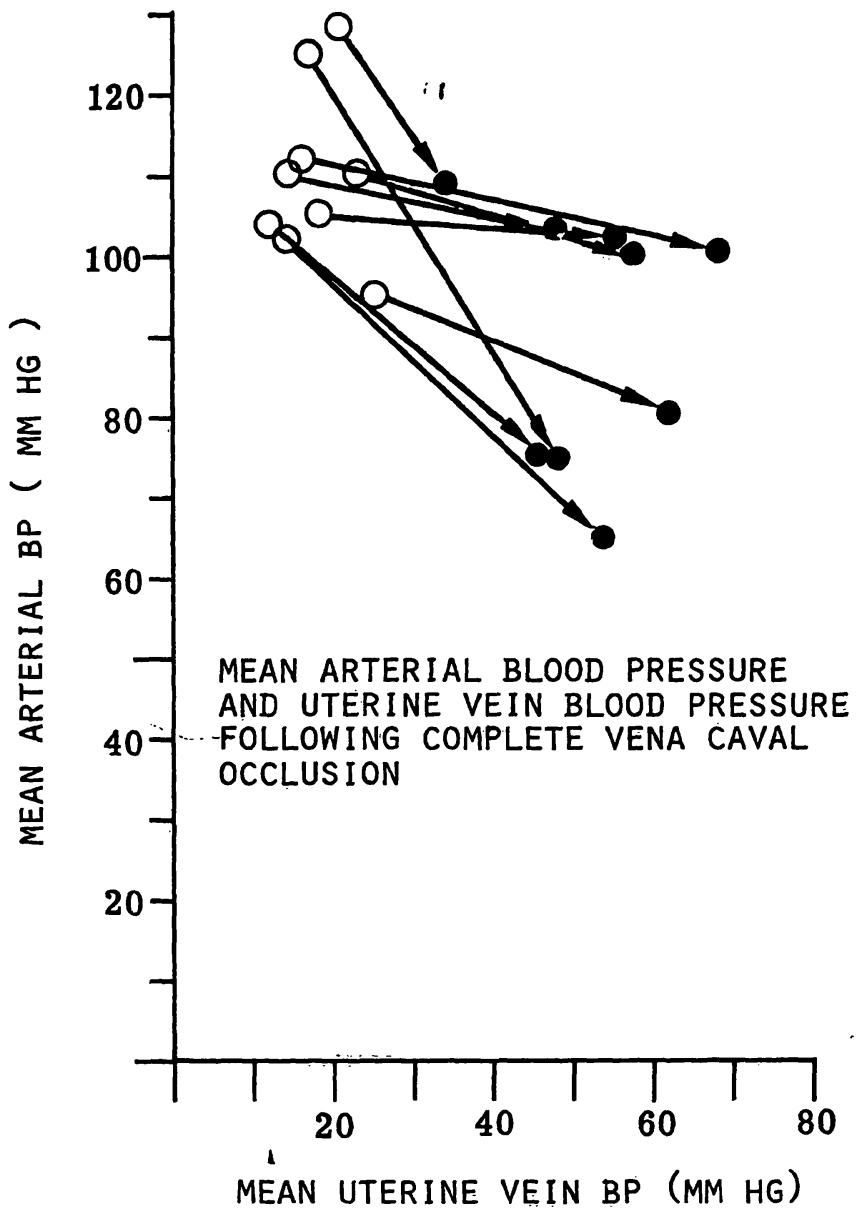

Fig. 2. Relationship between mean arterial blood pressure and uterine vein blood pressure before and during complete vena caval occlusion.

Following complete vena caval occlusion the uterine vein $\mathrm{BP}$ rose from $18 \pm 4 \mathrm{mmHg}$ to $53 \pm 10 \mathrm{mmHg}$. The rise in uterine vein BP was not always accompanied with a profound fall in mean arterial BP. The drop of mean arterial $\mathrm{BP}$ ranged from $1 \mathrm{mmHg}$ to $50 \mathrm{mmHg}$.

SD 62) shows, that complete V.C. O. is not always accompanied with a profound decrease in mean arterial $\mathrm{BP}$, even if the rise in uterine vein $\mathrm{BP}$ is nearly the same (Fig. 2). In 4 cases the maternal blood pressure fell $34 \pm 13 \mathrm{mmHg}$ by an increase of uterine vein blood pressure of $30 \pm$ $11 \mathrm{mmHg}$, in 5 other cases the same rise in uterine vein blood pressure $(39 \pm 8 \mathrm{mmHg}$ ) led to a decrease of maternal blood pressure of $9 \pm 5 \mathrm{mmHg}$ only.

\subsubsection{Uterine blood flow and uterine vascular resistance}

Related to the increase in uterine vein blood pressure and decrease in maternal blood pressure, blood flow fell dramatically to $62 \pm 18 \%$ and 


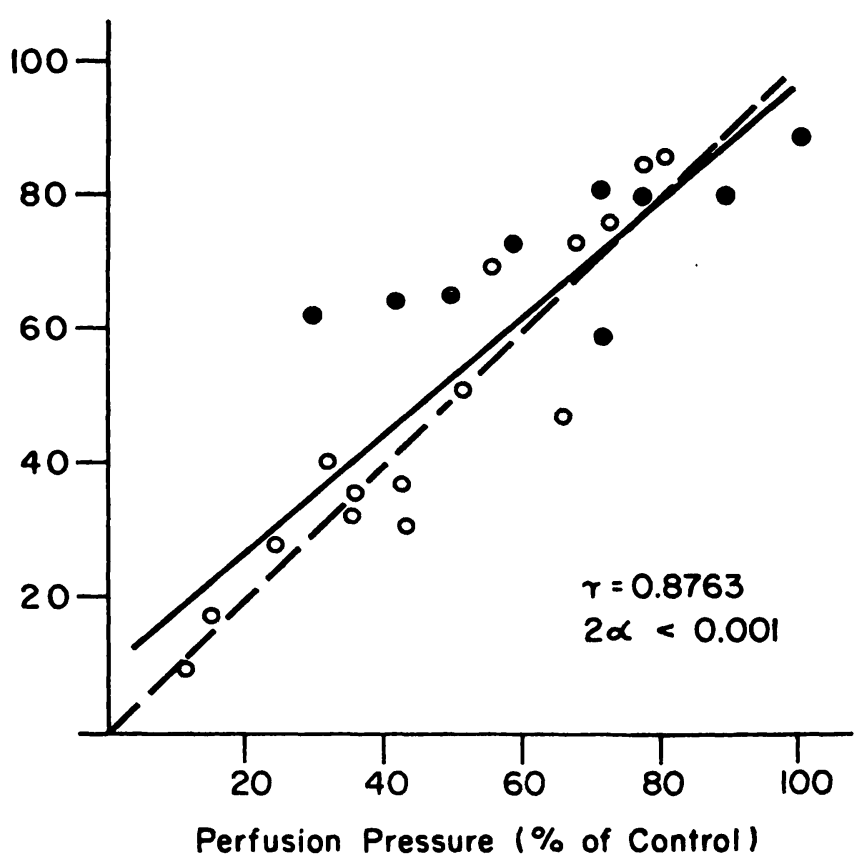

Fig. 3. Uterine blood flow and perfusion pressure 2 minutes after starting vena caval occlusion. Both are given as \% of control. The circels indicate the response in sheep with alive fetuses, the filled circels with dead fetuses.

The calculated regression line (solid line) for both, dead and alive fetuses, is not significantly different from the line that one would expect if the drop in blood flow is proportional to the decrease in perfusion pressure (dotted line).
$57 \pm 25 \%$ of its control value, respectivly (Fig. 1). The reduction of uterine blood flow is proportional to the decrease of the perfusion pressure i. e. the difference of maternal blood pressure and uterine vein blood pressure. In Figure 3 the uterine blood flow is plotted against the perfusion pressure, both as percent of control. The circles indicate the relationship between these two parameters in sheep with alive fetuses and the dots with dead fetuses, following vena caval occlusion of 2 minutes. The calculated regression line is not significantly different from the theoretical relationship of pressure and flow, which exists if the vascular resistance is constant. These findings demonstrate that during $2 \mathrm{mi}-$ nutes of vena caval occlusion, there is no increase in uterine vascular resistance.

In Fig. 4 the uterine vascular resistance before, during and after vena caval occlusion is shown. No significant change in the resistance during and following vena caval occlusion could be measured.

The decrease in uterine blood flow is mainly related to the rise in uterine vein blood pressure as it is shown in a single case in Fig. 5.

\section{(\% of Control) Uterine Vasculare Resistance}

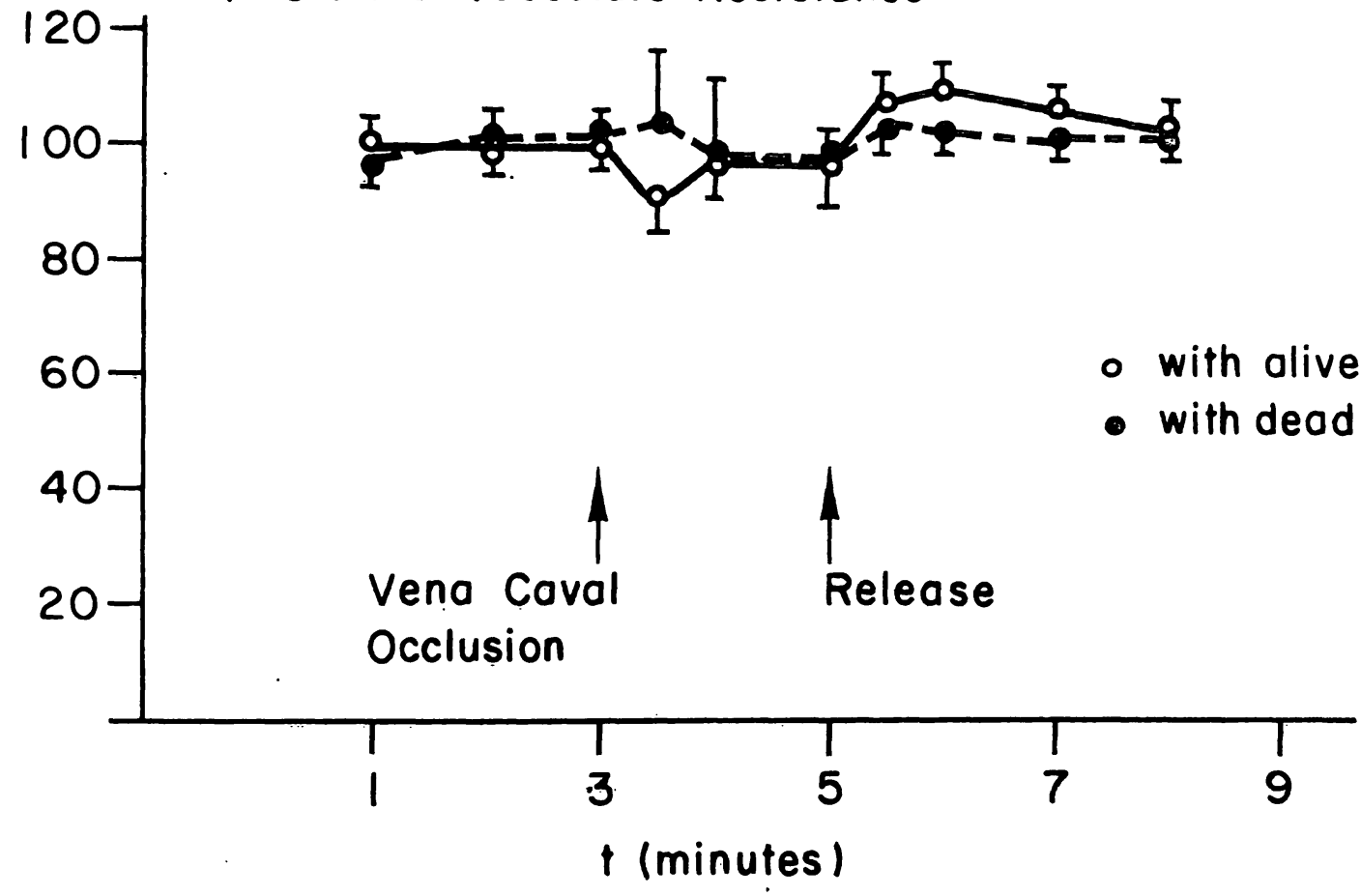

Fig. 4. Uterine vascular resistance before, during and after vena caval occlusion in sheep with alive fetuses ( $O ; N=$ 15) and with dead fetuses $(0 ; N=9)$. The values are given as percent of control (Mean $\pm S$. E.).

There is no significant change in uterine vascular resistance following vena caval occlusion. 


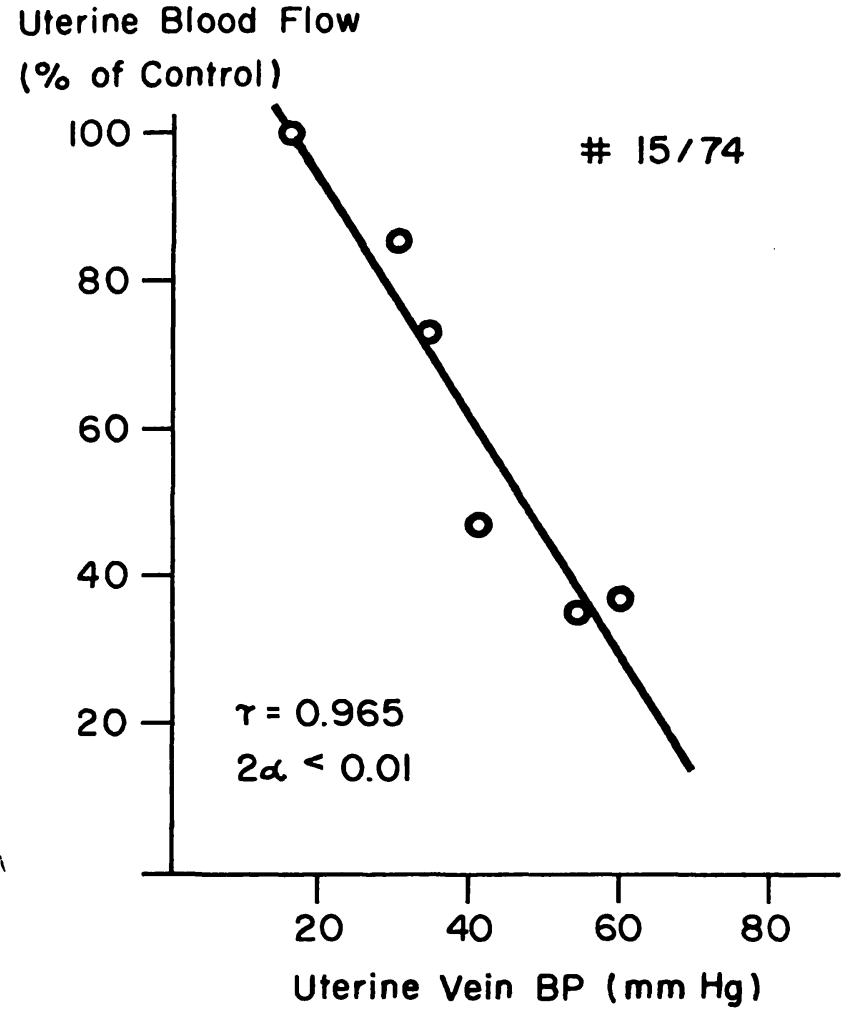

Fig. 5. Relationship of uterine blood flow (\% of control) and the rise in uterine vein blood pressure in sheep \# 15/74. In 5 vena caval occlusion of varying degree there was a good correlation between the increase in vein pressure and the decrease in uterine blood flow. The mean drop in arterial blood pressure was $8 \mathrm{mmHg}$ (SD 2.3).

\subsubsection{The amniotic fluid pressure}

The pressure of the amniotic fluid in each experiment showed a small but significant increase of $2 \mathrm{mmHg}$. The rise of amniotic fluid pressure resulted from obstructing the vena cava and thus led to blood congestion in the vessels of the uterus. This increased the tension of uterine wall. The amniotic fluid pressure fell to its initial value within few seconds after releasing V. C. O.

\subsection{Fetal heart rate and fetal aortic blood pressure following vena caval occlusion}

\subsubsection{Fetal heart rate and uterine blood flow}

During vena caval occlusion fetal heart rate was associated with the fall in uterine blood flow (Fig. 6). The heart rate before occlusion was $218 \pm 41 \mathrm{~b} / \mathrm{min}$. it dropped to $210 \pm 38 \mathrm{~b} / \mathrm{min}$. $30 \mathrm{sec}$. after occlusion of the V. C. and reached its lowest level 2 minutes after occlusion:

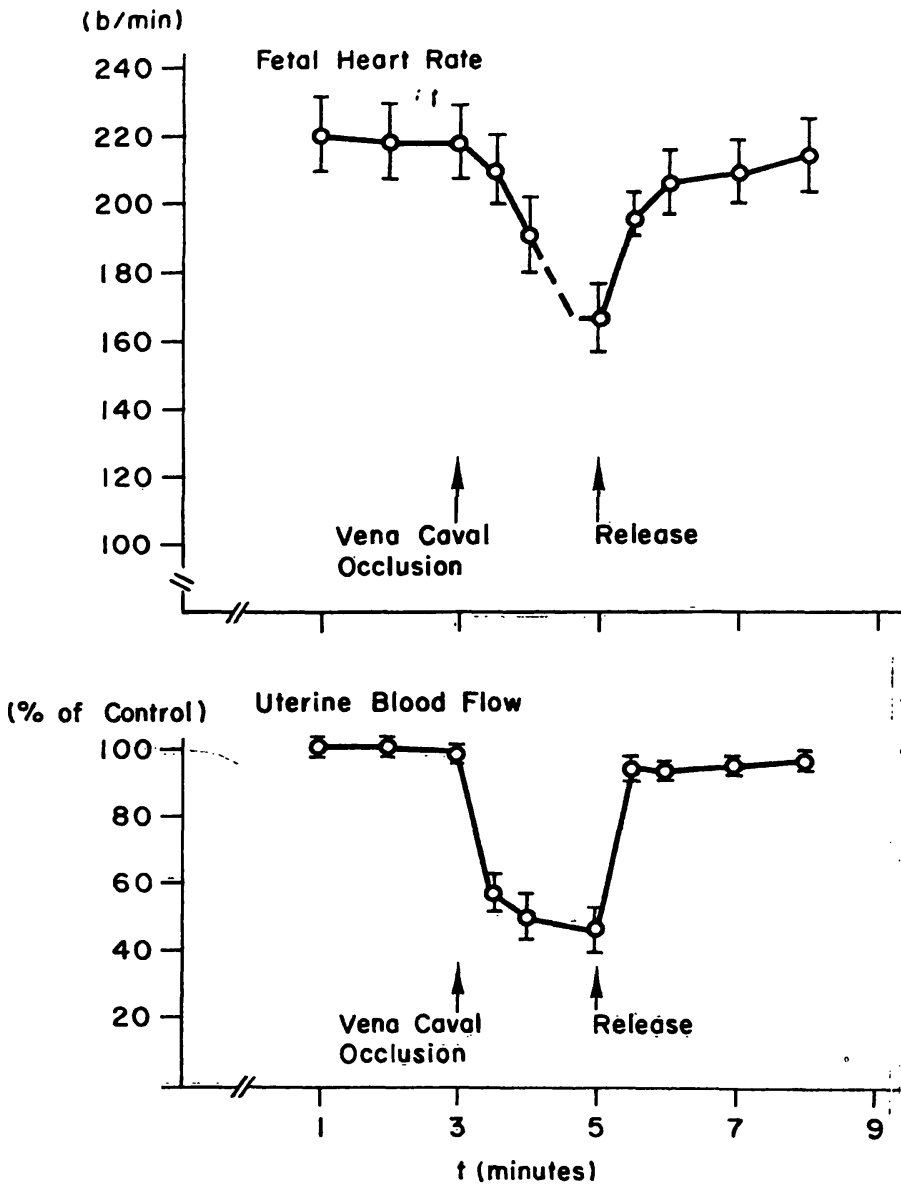

Fig. 6. Fetal heart rate and uterine blood flow before, during and after vena caval occlusion in 15 experiments (Mean \pm S. E.). With the decrease in uterine blood flow there was a delayed decrease in fetal heart rate. The control value was achieved about 3 minutes after release.

$166 \pm 36 \mathrm{~b} / \mathrm{min}$. After releasing the compression the fetal heart rate rose again reaching its control value 3 minutes after release.

As Fig. 7 shows the drop in fetal heart rate as a maximum response after 2 minutes occlusion was correlated to the fall in uterine blood flow. A $30 \%$ flow reduction did not alter fetal heart rate significantly, but a flow reduction below $50 \%$ was associated with a remarkable drop in fetal heart rate.

Fig. 8 shows fetal heart rate in $\mathrm{b} / \mathrm{min}$. in 7 experiments before, during and following vena caval occlusion. In low and high fetal heart rate baseline a flow reduction below $50 \%$ is always followed by a decrease in fetal heart rate. A reduction in uterine blood flow to about $30 \%$ is associated with an increase in fetal heart rate. 
Fetol Heort Rate

(\% of Control)

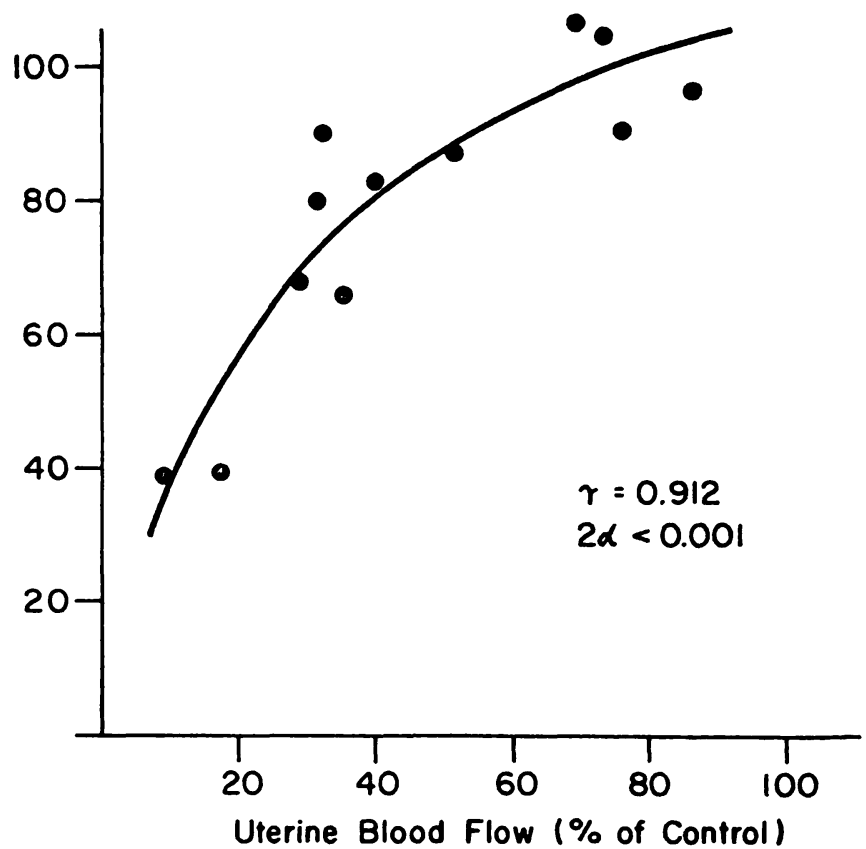

Fig. 7. Response of fetal heart rate 2 minutes after vena caval occlusion related to uterine blood flow, both as percent of control. Only a slight increase or decrease in fetal heart tate is found if the blood flow was lowered to $50 \%$ of its control value. A significant change in fetal heart rate took place if uterine blood flow fell below $50 \%$. A logarithmic regression line is adapted to the respective data (FHR $=\log$ UBF. $71.1-33.2,2 \alpha<0.001)$.

(b/min) Fetal Heart Rote

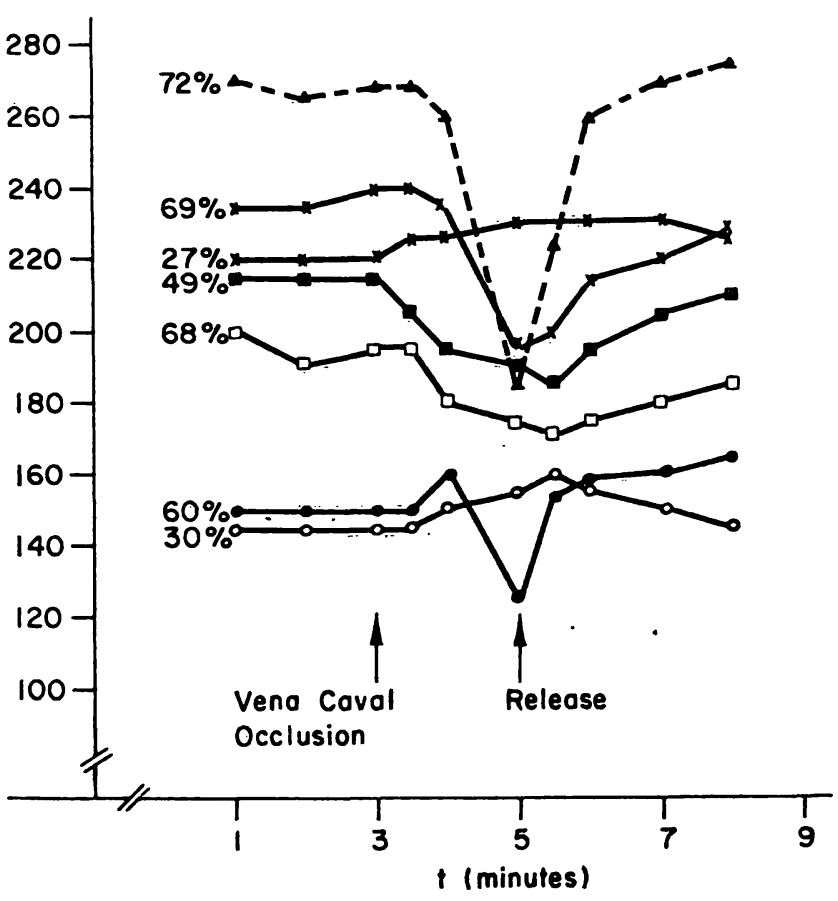

\subsubsection{Fetal aortic blood pressure}

During the occlusion of the vena cava the decrease in fetal heart rate was paralleled by a slight but significant increase in arterial blood pressure of the fetus. The blood pressure before occlusion was $59 \pm 9 \mathrm{mmHg}$ and rose during occlusion to $62 \pm 9 \mathrm{mmHg}$. The increase is significant using the 'T-test' of paired analysis.

\section{Comments}

Uterine blood flow is as the blood flow of many other organs dependent on perfusion pressure i. e. the difference in blood pressure between the uterine artery and the uterine vein and the resistance which is located mainly in the preplacental vessels. During V. C. O. both of these parameters can be influenced leading to a decrease in uterine blood flow and affecting fetal oxygenation.

\subsection{The perfusion pressure, uterine vas- culare resistance and uterine blood flow}

The present results show clearly that uterine blood flow is decreased by a fall in perfusion pressure and not due to a rise in uterine vasculare resistance. The decrease of perfusion pressure is in $65 \%$ due to a rise in uterine vein blood pressure and only in $35 \%$ due to a decrease in mean arterial blood pressure. The rise in uterine vein pressure occures immediately after starting V. C. O. reaching its highest level about 30 sec. later (Fig. 1). Due to the reduced venous return to the heart maternal BP drops steadily leading to a further slight decrease in UBF.

The rise in uterine vein pressure is in consistency with the findings in humans [15].

The influence of V. C. O. on mean arterial blood pressure is of different kind (Fig. 2) Following complete V. C. O. there was in 5 sheep a de-

Fig. 8. Fetal heart rate in 7 experiments of 4 selected cases during and following vena caral occlusion shows the reaction at different baseline fetal heart rate. The percent values indicate reduction in uterine blood flow. In the present cases the reduction in uterine blood flow of $30 \%$ is followed by an increase in fetal heart rate baseline and a reduction of $50 \%$ and more results in a decrease in fetal heart rate. 
crease in arterial BP of $9 \mathrm{mmHg}$ and in 4 cases the maternal $\mathrm{BP}$ fell $34 \mathrm{mmHg}$ by the same rise in uterine vein BP. The same findings were reported in humans. ScoTt and KERR [15] found in pregnant women undergoing caesarean section by V. C. O. a decrease in cardiac output and no change in maternal blood pressure.

In women lying in supine position there is also a variable change in systemic arterial pressure. LEEs et al. [9] found in 6 cases no change or a rise in arterial blood pressure to $12 \mathrm{mmHg}$ and in 10 cases a decrease of $1-57 \mathrm{mmHg}$. But only in three cases a profound decrease in arterial blood pressure of about $55 \mathrm{mmHg}$ was found. For this fact exists no real explanation. One may speculate if it is due to the variable efficency of the collateral venous channels of the i uterus or due to a para-sympathetic response as suggested by KERR [15].

The decrease in venous blood returning to the maternal heart results in pregnant women undergoing a caesarean section or turning from lateral to supine position in a decrease in cardiac output and an increase in total peripheral resistance (TPR). (LEEs et al. [11], VORYs et al. [16], LeEs et al. [9]). The rise in TPR is usually accompanied by an increase in uterine vasculare resistance [7]. As Fig. 4 shows, there was in the present experiment no alteration in UVR during and following vena caval occlusion. A possible explanation for the lack of an increase in UVR might be the duration of vena caval occlusion. But the patient studied by LeES et al. showed that TPR rose even $2 \mathrm{~min}$. following supine position.

The question arises: Is this increase in reisistance due to a vasoconstriction in the arterial system mediated by elevated sympathicotone or is this resistance located in the vena cava caused by the fact that the uterus compressed this vessel? The latter hypothesis is supported by the fact that UVR did not increase within $2 \mathrm{~min}$. and that it disappeared releasing the occlusion. The distensibility of the venous system distal of the occlusion may be responsible for further, 'blood loss' into this system and leads to a profound drop in the maternal blood pressure and finally to a rise in peripheral i. e. arterial vascular resistance.

\subsection{Fetal heart (FHR) and fetal blood pressure (FBP) during vena caval oc- clusion}

The present experiments show that V. C. O. was followed by a decrease in FHR and rise in FBP. The mean elevated FHR and BP indicate that some fetuses were in stressed condition. $\mathrm{pH}$ determination were not done to proof this fact. However Fig. 8 shows that FHR reacts following V. C. O. was independent of FHR baseline i. e. the condition of the fetus. The decrease of FHR was delayed and the fall correlated to the decrease of UBF. This is in agreement with our previous findings showing the effect of reduction of uterine blood flow by compressing the aorta on alteration in fetal heart rate [3]. Power and Longo [12] pointed out that sluice flow in the placenta explains adequately the slowing of FHR during vena caval occlusion. The rise in venous pressure in the intervillous space obstruct the fetal capillaries and as a consequence fetal blood pressure rises and fetal heart rate slows down as a baroreceptore response. In these studies there was only a slight rise in fetal blood pressure during vena caval occlusion. The increase was $3.2 \pm 2.4 \mathrm{mmHg}$ after $10 \mathrm{sec}$. The increase was not correlated to the uterine venous pressure, that we would have expected. But the rise was correlated to the increase of amniotic fluid pressure that occured during V. C. O.

$(\Delta \mathrm{pa}, \mathrm{F}=0.46+1.2 \cdot \Delta \mathrm{p} \mathrm{A} ; 2 \alpha<0.001)$

We therefore assume that slowing of fetal heart rate in vena caval occlusion expresses more a reduced $\mathrm{O}_{2}$-supply to the fetus than a baroreceptor response. 


\section{Summary}

The present experiments should show if vena caval occlusion (V. C. O.) results in a decrease in uterine blood flow and an increase in uterine vasculare resistance (UVR). We were further interested to know, if V.C. O. influences fetal heart rate (FHR) and fetal blood pressure (BP).

The experiments were performed on eight sheep with a gestational age of 110 till 135 days. Uterine blood flow was measured with a flow probe placed around the right uterine artery. The blood pressure (BP) was measured in the femoral artery, uterine vein and aorta of the fetus. The amniotic fluid pressure was also measured. V.C. O. was performed complete 9 times and of varying degree 15 times.

Vena caval occlusion and uterine hemodynamics

Following V. C. O. the BP in the uterine vein rose form $17 \mathrm{mmHg}$ to $43 \mathrm{mmHg}$ and the BP in the artery dropped from $105 \mathrm{mmHg}$ to $91 \mathrm{mmHg} 2$ minutes after occlusion (Fig. 1), i. e. the perfusion pressure was reduced by 40 $\mathrm{mmHg}$.

The reduction in blood flow was proportional to the decrease in perfusion pressure i.e. the UVR remained constant (Fig. 3 and 4). The fall of the arterial BP was not correlated to the rise in uterine vein BP.

Fetal heart rate (FHR), fetal arterial blood pressure (BP) and vena cava occlusion (V. C. O.)

Following V.C. O. fetal heart tate fell by $24 \%$. The decrease was related to the fall in uterine blood flow (Fig. 6).

The BP of the fetus rose by $3 \mathrm{mmHg}$.

The results show clearly, that UBF during V.C. O. is reduced by $a$ fall in perfusion pressure and not due to a rise in $U$. V. R. The decrease in fetal HR is related to the fall of uterine blood flow.

Keywords: Fetal heart rate, perfusion pressure, uterine blood flow, vascular resistance, vena caval occlusion.

\section{Zusammenfassung}

Uterine Hämodynamik und fetale Reaktion auf den Verschluß der vena cava beim Schaf

Mit den vorliegenden Experimenten sollte untersucht werden ob während der Kompression der Vena cava (V. C. K.) die Uterusdurchblutung abfällt und ob der uterine Gefäßwiderstand ansteigt. Weiterhin interessierte das Verhalten der fetalen Herzfrequenz während der V. C. $K$.

Die Experimente wurden bei 8 Schafen mit einem Gestationsalter von 110 bis 135 Tagen durchgeführt. Es wurde die Durchblutung der rechten Arteria uterina bestimmt und der Blutdruck in der Arteria femoralis und Vena uterina der Mutter und in der Aorta des Feten gemessen. Der Amniondruck wurde ebenfalls mit einem Druckaufnehmer bestimmt. Die Vena cava wurde $9 \mathrm{mal}$ vollständig und $15 \mathrm{mal}$ in variierender Stärke komprimiert. Die Uterusdurchblutung und der uterine Gefäßwiderstand wurden in Prozent vom Kontrollwert angegeben. Die fetale Herzfrequenz wurde kontinuierlich unter Verwendung des fetalen EKG registriert.

Vena Cava Kompression und uterine HämodynamikBei der V. C. K. stieg der Blutdruck in der Vena uterina im Mittel von $17 \mathrm{mmHg}$ auf $43 \mathrm{mmHg}$ an und der arterielle
Mitteldruck fiel von $105 \mathrm{mmHg}$ auf $91 \mathrm{mmHg}$ ab (2 Minuten nach Kompression) (Fig. 1), d. h. der Perfusionsdruck am Uterus wurde durch die V. C. K. um $40 \mathrm{mmHg}$ reduziert.

Die Reduktion der Uterusdurchblutung war dem Abfall des Perfusionsdruckes proportional, d.h. der uterine Gefäßwiderstand blieb konstant (Fig. 3 und 4). Der Abfall des arteriellen Mitteldruckes war nicht zum Anstieg des Blutdruckes in der Vena uterina korreliert.

Fetale Herzfrequenz, arterieller Blutdruck und Vena cava Kompression

Die fetale Herzfrequenz (FHF) fiel durch die V. C. K. um 24\% ab. Der Abfall der FHF war zur Reduktion der uterinen Durchblutung korreliert (Fig. 6). Der Blutdruck des Feten stieg durch die V. C. K. um $3 \mathrm{mmHg}$ an. Die vorliegenden Ergebnisse zeigen deutlich, daß die uterine Durchblutung während der V.C.K. reduziert wird, weil der Perfusionsdruck abfällt. Der uterine Gefäßwiderstand bleibt konstant. Der Abfall der fetalen Herzfrequenz ist zum Abfall der uterinen Durchblutung korreliert.

Schlüsselwörter: Fetale Herzschlagfrequenz, Fetus, Gefäßwiderstand, Perfusionsdruck, Uterusdurchblutung, Vena cava Kompression.

\section{Résumé}

Hémodynamique utérine et réponse foetale à l'occlusion de la veine cave chez le mouton

Les expériences présentes ont été faites dans le but de vérifier si la compression de la veine cave (C. V. C.) entraîne une baisse de l'irrigation sanguine de l'utérus ou une hausse de la résistance vasculaire utérine. L'attention a été également attirée par le comportement de la fréquence cardiaque foetale pendant la C. V.C.

Ces expériences ont été effectuées sur 8 moutons en âge de gestation situé entre 110 et 135 jours. On a déterminé l'irrigation de l'artére utérine droite et mesuré la pression sanguine dans l'artère fémorale et la vene utérine de la 
mère et dans l'aorte du foetus. On a également défini la pression amniotique à l'aide d'un enregistreur. La veine cave a été comprimée 9 fois de façon complète et 15 fois à des degrés différents. L'irrigation de l'utérus et la résistance vasculaire utérine ont été indiquées en pourcentage relatif à la valeur de contrôle. La fréquence cardiaque foetale a été enregistrée de façon continue par ECG du foetus.

\section{Compression de la veine cave et hémodynamique utérine}

Sous l'effet de la C. V.C., la pression sanguine de la veine utérine a monté en moyenne de $17 \mathrm{mmHg}$ à 43 $\mathrm{mmHg}$ et la pression artérielle moyenne a baissé de $105 \mathrm{mmHg}$ à $91 \mathrm{mmHg}$ (2 minutes après la compression) (Fig. 1), c. à. d. que la pression de perfusion à l'utérus a été réduite de $40 \mathrm{mmHg}$ par la C. V. C.

$\mathrm{La}$ réduction de l'irrigation uterine a été proportionnelle à la baisse de la pression de perfusion, c. à. d. que la résis- tance vasculaire utérine est restée constante (Fig. 3 et 4). On n'a observé aucune corrélation entre la baisse de la pression moyenne artérielle 'ét la hausse de la pression sanguine dans la veine utérine.

Fréquence cardiaque foetale, pression artérielle et compression de la veine cave

La fréquence cardiaque foetale (F. C. F.) a baissé de $24 \%$ par suite de la C.V.C. On a observé une corrélation entre la baisse de la FCF et la réduction de l'irrigation utérine (Fig. 6). La pression sanginue du foetus a augmenté de $3 \mathrm{mmHg}$ par suite de la CVC.

Les résultats obtenus prouvent bien que l'irrigation utérine a été réduite pendant la CVC, la pression de perfusion diminuant. La résistance vasculaire utérine reste constante. Il existe une corrélation entre la baisse de la fréquence cardiaque foetale et la diminution de l'irrigation utérine.

$$
\text { - - - . - . }
$$

Mots-clés: Fréquence cardiaque foetale, irrigation sanguine utérine, occlusion de la veine cave, pression de perfusion, résistance vasculaire.

\section{Bibliography}

[1] Hon, H. H., B. L. ReId, F. W. Hehre: The electronic evaluation of fetal heart rate Amer. J. Obstet. Gynec. 79 (1960) 209

[2] Howard, B. K., J. H. Goodson, W. F. Mengert: Supine hypotensive syndrom in late pregnancy. Obstet. Gynec. 1 (1953) 371

[3] Junge, H. D., W. Künzel, F. K. Klöck: Die Dynamik der fetalen Herzfrequenz-Regulation bei akuter Drosselung der uterinen Durchblutung. In: SALING, E., J. W. Dudenhausen: Perinatale Medizin Bd. 4 Thieme, Stuttgart 1973

[4] Kerr, M. G., D. B. Scott, E. Samuel: Studies of the Inferior Vena Cava in Late Pregnancy. Brit. Med. J. 1 (1964) 532

[5] KERR, M. G.: The mechanical effects of the gravid uterus in late pregnancy. J. Obstet. Gynaec. Brit. Cwlth. 72 (1965) 513

[6] KüNZEL, W.: Die Bedeutung der Uterusdurchblutung für die Sauerstoffversorgung des Fetus. Nieders. Ärzteblatt 45 (1972) 479

[7] KüNZEL, W.: Der Zusammenhang zwischen Durchblutung und Gefäßwiderstand des Uterus. In: SALING, E., J. W. Dudenhausen: Perinatale Medizin Bd. 3, Thieme, Stuttgart 1972

[8] KÜNZEL, W., W. MoLL: Uterine $\mathrm{O}_{2}$-consumption and blood flow of the pregnant uterus. Z. Geburtsh. u. Perinat. 177 (1972) 108
[9] LeEs, M. M., D. B. ScotT, M. G. KERR, S. H. TAYLOR: The circulatory effects of recumbent postural change in late pregnancy. Clin. Science 32 (1967) 453

[10] Lees, M. M., S. H. TAYLOR, D. B. Scott, M. G. KerR: A study of cardiac output at rest throughout pregnancy. J. Obstet. Gynaec. Brit. Cwlth. 74 (1967) 319

[11] Lees, M. M., D. B. Scott, K. B. Slawson, M. G. KERR: Haemodynamic changes during caesarean section. J. Obstet. Gynaec. Brit. Cwlth. 75 (1968) 546

[12] Power, G. G., L. D. Longo: Sluice flow in placenta: maternal vascular pressure effects on fetal circulation. Amer. J. Physiol. 225 (1973) 1490

[13] Roberts, W. A. Mc.: Postural shock in pregnancy. Amer. J. Obstet. Gynec. 62 (1951) 627

[14] Reed, N. E., N. J. Teteris, G. F. Essig: Inferior vena caval obstruction syndrome with electrocardiographically documented fetal bradycardia. Obstet. Gynec. 36 (1970) 462

[15] Scotr, D. B., M. G. KERR: Inferior vena caval pressure in late pregnancy. J. Obstet. Gynaec. Brit. Cwlth. 70 (1963) 1044

[16] Vorys, N., J. C. Ullery, G. E. HanuseK: The cardiac output changes in various positions in pregnancy. Amer. J. Obstet. Gynec. 82 (1961) 1321

Prof. Dr. W. Künzel

Univ.-Frauenklinik

Josef-Schneider-Str. 4

D-8700 Würzburg 